\title{
Recent retreat of ice cliffs, King George Island, South Shetland Islands, Antarctic Peninsula
}

\author{
Byong-Kwon Park, ${ }^{2}$ Soon-Keun Chang, ${ }^{1}$ Ho Il Yoon, ${ }^{1}$ Hosung Chung ${ }^{1}$ \\ ${ }^{1}$ Polar Research Center, ${ }^{2}$ Korea Ocean Research and Development Institute, Ansan P.O. Box 29, Seoul 425-600, Korea
}

\begin{abstract}
Comparison of aerial photos shows that the ice cliff in Marian Cove, Maxwell Bay, southwestern King George Island, retreated approximately $250 \mathrm{~m}$ between 1956 and 1986, but advanced about $40 \mathrm{~m}$ between December 1986 and January 1989. The advance in the late 1980 s seems to be related to the cold austral winters of 1986-88. A topographic survey in January 1994 revealed that the ice cliff in Marian Cove had again retreated around $270 \mathrm{~m}$ since January 1989; approximately the same as from December 1956 to December 1986. In Potter Cove, the ice cliff retreated approximately $400 \mathrm{~m}$ from 1956-89. The more pronounced retreat here may be attributable to shallower water depths $(<30 \mathrm{~m})$. These ice cliffs retreats are discussed as a possible consequence of recent regional warming.
\end{abstract}

\section{INTRODUCTION}

Changes in the Antarctic ice shelf are likely results of atmospheric warming. They include the melting of glacier margins and retreat of ice shelves. Melting and the disappearance of ice shelves have already been observed around the Antarctic Peninsula (Doake and Vaughan, 1991; Skvarca, 1993; Ward, 1995; Vaughan and Doake, 1996), including deglaciation in East Antarctica (Burgess and others, 1994) and glacier fluctuations in South Georgia (Gordon and Timmis, 1992).

Marian and Potter Coves are fjords in Maxwell Bay, southwestern King George Island, South Shetland Islands, off the northern tip of the Antarctic Peninsula (Fig. 1). Marian Cove lies northeast-southwest and is $1.3 \mathrm{~km}$ wide and $3 \mathrm{~km}$ long. Potter Cove is $1.4 \mathrm{~km}$ wide and $3.5 \mathrm{~km}$ long. The inner parts of the coves are rimmed with ice cliffs 5 to $30 \mathrm{~m}$ high and 15 to $40 \mathrm{~m}$ high, respectively.

This paper describes ice-cliff retreat in these small fjords over the past few decades based on evidence from aerial photographs and topographic surveys.

\section{MATERIALS AND METHODS}

Aerial photographs were obtained from the Royal Navy which surveyed Marian and Potter Coves on 20 December 1956 and 4 January 1989. Marian Cove was also photographed by the Chilean Air Force on 21 December 1986.

The Marian Cove ice cliffs were investigated in January 1994 by the Korea Ocean Research and Development Institute (KORDI) during a topographic survey of Barton Peninsula (Kim and Baek, 1995; KORDI, 1996). King Sejong station is located on Barton Peninsula, a promontory $8.5 \mathrm{~km}$ by $9.5 \mathrm{~km}$ between Marian and Potter Coves. These surveys allowed a detailed mapping of the ice cliffs.

The ice cliffs in the aerial photographs and figure 3 of Kim and Baek (1995) were digitized for image analysis. Changes in the ice-covered area and the amount of ice-wall retreat were obtained with reference to the topographic map.

\section{RESULTS AND DISGUSSION}

Comparison of the aerial photographs of Marian Cove showed the ice-covered area reduced by about $280000 \mathrm{~m}^{2}$ from December 1956 to December 1986 but increased by $45000 \mathrm{~m}^{2}$ from December 1986 to January 1989. The January 1994 topographic survey revealed that the ice front in the cove had retreated again since January 1989, and an area of $290000 \mathrm{~m}^{2}$ had been lost (Table 1). Overall, the ice cliff (around $1100 \mathrm{~m}$ long) retreated up to $680 \mathrm{~m}$ with a mean of $480 \mathrm{~m}$ from December 1956 to January 1994 (Fig. 2).

In Potter Cove, the ice cliff (around $1000 \mathrm{~m}$ long) retreated up to $490 \mathrm{~m}$ with a mean of $400 \mathrm{~m}$ and an area of

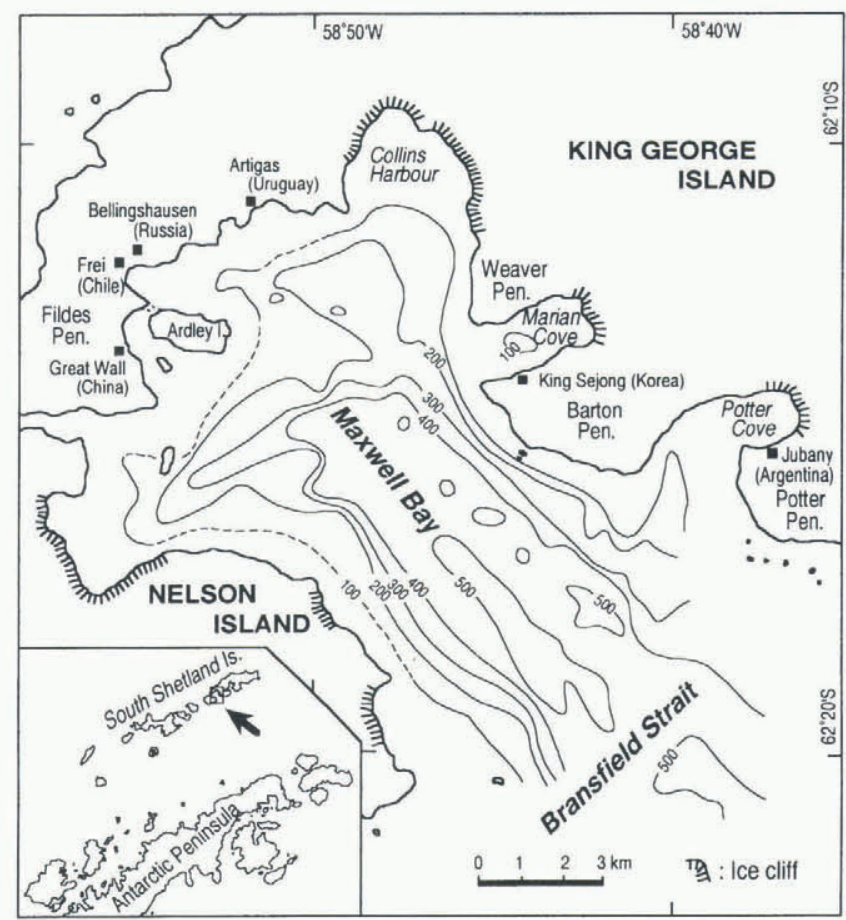

Fig. 1. Study area on King George Island. 
Table 1. Recent retreat of ice cliffs from air photo image analysis and topographic survey, King George Island

\begin{tabular}{|c|c|c|c|c|}
\hline & Period & $\begin{array}{c}\text { Areal } \\
\text { reduction }\end{array}$ & $\begin{array}{c}\text { Mean length } \\
\text { change }\end{array}$ & $\begin{array}{l}\text { Max. length } \\
\text { change }\end{array}$ \\
\hline & & $\mathrm{m}^{2}$ & $\mathrm{~m}$ & $\mathrm{~m}$ \\
\hline \multirow[t]{4}{*}{ Marian Cove } & Dec 1956-Dec 1986 & 278669 & 253 & 378 \\
\hline & Dec 1986-Jan 1989 & -44699 & -41 & -100 \\
\hline & Jan 1989-Jan 1994 & 292965 & 266 & 389 \\
\hline & Total & 526935 & 478 & 683 \\
\hline Potter Cove & Dec 1956-Jan 1989 & 360600 & 398 & 488 \\
\hline
\end{tabular}

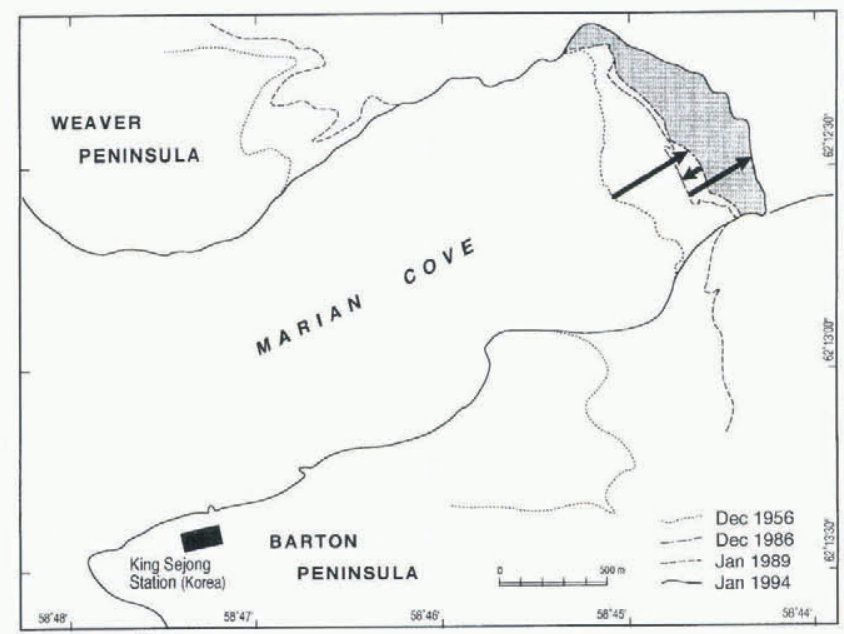

Fig. 2. Retreat of Marian Cove ice cliff. Note the advance nearly equivalent to the retreat over 30 years (December 1956 and December 1986) and during 5 years (January 1989 and January 1994).

$360000 \mathrm{~m}^{2}$ was lost from December 1956 to January 1989 (Fig. 3). The ice retreats were likely related to cyclic changes, and advances would have been possible during cold spells.

The mean annual air temperature at Presidente Eduardo Frei base (Chile), on Fildes Bay about $13 \mathrm{~km}$ from Marian Cove, showed that 1989 was the warmest year since 1970 (Fig. 4). Air temperatures at King Sejong station (Korea), measured since February 1988, also showed the same characteristics (Table 2). Recently, 1989 seems to have been the warmest year, at least in the western part of the Antarctic Peninsula, according to records from King George Island as well as Faraday (1957-89) and Marguerite Bay (1962-89) (Morrison, 1990).

On the other hand, the advance of the Marian Cove ice cliff by 10-100 m from December 1986 to January 1989 (Table 1), with a likely mean value of $41 \mathrm{~m}$, may be related to the cold spell between 1986 and 1988 (Fig. 4). Until 1996, 1988 was one of the coldest years at King Sejong station, with a yearly mean temperature of $-2.5^{\circ} \mathrm{C}$ (Table 2 ).

Marian and Potter Coves have nearly the same surface area. However, the area of ice loss in Potter Cove (around $360000 \mathrm{~m}^{2}$ ) is about one-and-a-half times larger than that in Marian Cove (around $230000 \mathrm{~m}^{2}$ ) from December 1956 to January 1989 (Table 1). The catchment basin area of Marian Cove at $9.5 \mathrm{~km}^{2}$ is close to that of Potter Cove at $9.4 \mathrm{~km}^{2}$, as shown by the 1:200000 scale map published by the Defense Mapping Agency Hydrographic/Topographic Center (1980). Thus, catchment basin area cannot be the

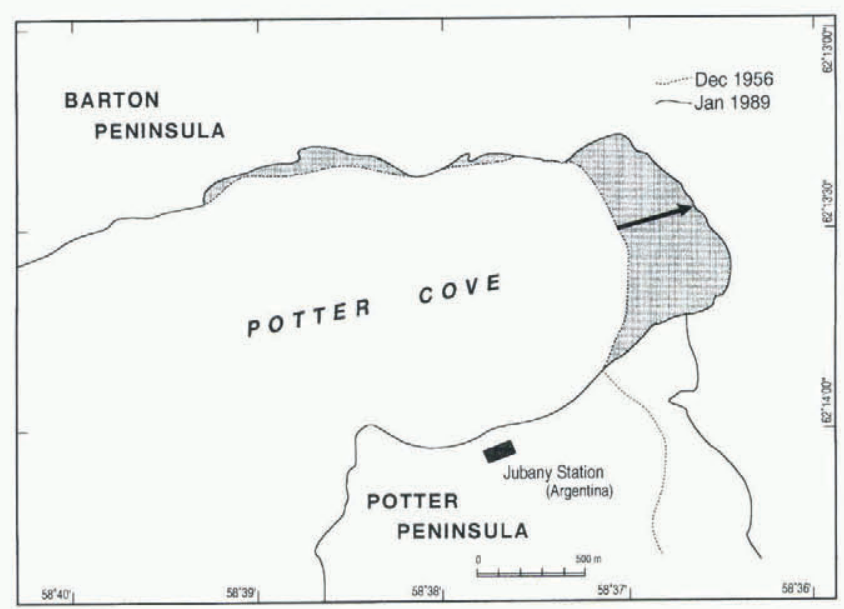

Fig. 3. Retreat of Potter Cove ice cliff from December 1956 to January 1989.

main cause of the greater retreat in Potter Cove. An alternative factor may be the difference in depth of the two fjords. Marian Cove is more than $130 \mathrm{~m}$ deep (Kim and Baek, 1995) while Potter Cove is only about $30 \mathrm{~m}$ deep (IHA, 1980). Due to the shallower depth, the ice cliff in Potter Cove may be grounded while that in Marian Cove may be floating or less firmly aground. This difference in thickness may be responsible for the larger area retreat in Potter Cove.

The monthly mean air temperatures from December to March at King Sejong station are above zero and the breakups of the ice cliff presumably occur mainly in that season. Infrequent rain from October to April might produce icemelt water which could trigger the breakup of the glacier (Doake and Vaughan, 1991).

The freezing of Marian Cove is unlikely to hamper the disappearance of ice cliffs as the ice calving is independent of the sea ice around the cliffs. The water around them is not frozen except in full winter, even if Maxwell Bay and Marian Cove may be frozen from May or June to September, and they do not freeze every year. For example, the bay and the cove were not frozen in the austral winters of 1989 , 1994 and 1996 since 1988. Duration of freezing of the cove varies from $<1$ month to 4 months with ice thickness varying from $60 \mathrm{~cm}$ or less according to the meteorological measurements and observation of sea ice at King Sejong

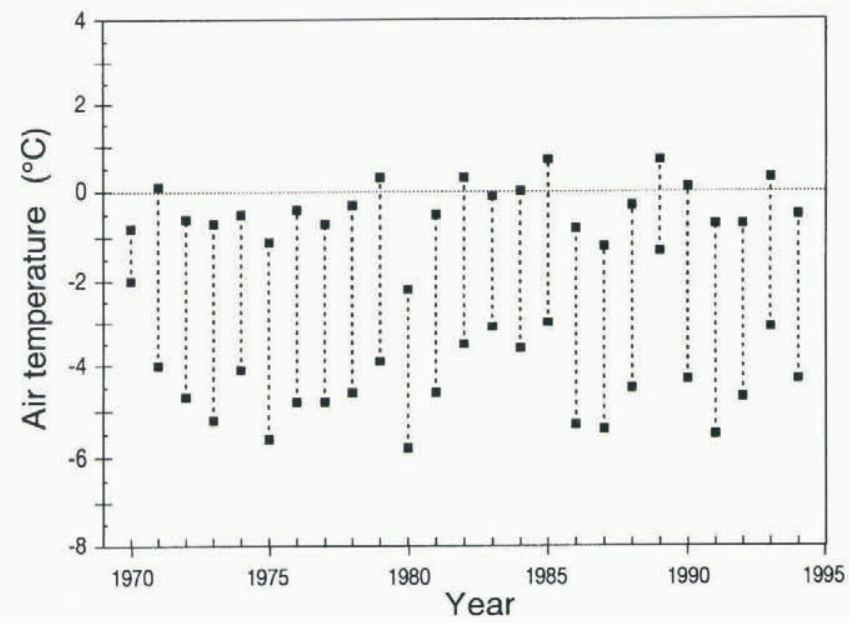

Fig. 4. Mean annual maximum and minimum air temperatures at Presidente Eduardo Frei Base, King George Island, 1970-94. 
Table 2. Monthly mean air temperature $\left({ }^{\circ} \mathrm{C}\right)$ and freezing of sea, King Sejong station, Barton Peninsula, King George Island

\begin{tabular}{|c|c|c|c|c|c|c|c|c|c|c|c|c|c|}
\hline Year & Jan. & Feb. & Mar. & Apr. & May & Jun. & Jul. & Aug. & Sep. & Oct. & Nov. & Dec. & Annual \\
\hline 1988 & - & 2.3 & -0.1 & -1.1 & -1.9 & $\begin{array}{l}-7.6 \\
\mathrm{MC}^{\mathrm{a}}\end{array}$ & $\begin{array}{l}-4.8 \\
\mathrm{MC}^{\mathrm{c}} \\
\mathrm{MB}^{\mathrm{c}}\end{array}$ & $\begin{array}{c}-8.4 \\
\mathrm{MC}^{\mathrm{c}} \\
\mathrm{MB}^{\mathrm{b}}\end{array}$ & $\begin{array}{l}-3.2 \\
\mathrm{MC}^{\mathrm{b}} \\
\mathrm{MB}^{\mathrm{b}}\end{array}$ & -2.6 & -1.1 & 0.5 & -2.5 \\
\hline 1989 & 1.5 & 2.4 & 2.3 & -4.8 & -0.9 & -2.0 & $\begin{array}{l}-0.7 \\
\mathrm{MC}^{\mathrm{a}}\end{array}$ & -2.1 & -3.0 & -0.6 & 0.2 & 1.4 & -0.5 \\
\hline 1990 & 2.3 & 2.7 & 1.2 & $\begin{array}{l}-4.8 \\
\mathrm{MC}^{\mathrm{a}}\end{array}$ & $\begin{array}{l}-4.9 \\
\mathrm{MC}^{\mathrm{a}}\end{array}$ & $\begin{array}{l}-4.2 \\
\mathrm{MC}^{\mathrm{a}}\end{array}$ & $\begin{array}{l}-5.3 \\
\mathrm{MC}^{\mathrm{a}}\end{array}$ & $\begin{array}{l}-5.3 \\
\mathrm{MC}^{\mathrm{a}}\end{array}$ & -2.7 & -1.9 & -0.8 & 0.7 & -1.9 \\
\hline 1991 & 2.2 & 0.8 & -0.2 & -2.3 & -7.2 & $\begin{array}{l}-8.8 \\
\mathrm{MC}^{\mathrm{a}} \\
\mathrm{MB}^{\mathrm{a}}\end{array}$ & $\begin{array}{l}-6.5 \\
\mathrm{MC}^{\mathrm{b}} \\
\mathrm{MB}^{\mathrm{b}}\end{array}$ & $\begin{array}{l}-6.6 \\
\mathrm{MC}^{\mathrm{c}} \\
\mathrm{MB}^{\mathrm{c}}\end{array}$ & $\begin{array}{l}-2.9 \\
\mathrm{MC}^{\mathrm{b}} \\
\mathrm{MB}^{\mathrm{a}}\end{array}$ & $\begin{array}{l}-3.5 \\
\mathrm{MC}^{\mathrm{a}}\end{array}$ & -0.8 & -0.2 & -3.0 \\
\hline 1992 & 1.8 & 0.8 & -1.1 & -0.7 & $\begin{array}{l}-8.0 \\
\mathrm{MC}^{\mathrm{a}} \\
\mathrm{MB}^{\mathrm{a}}\end{array}$ & $\begin{array}{l}-7.7 \\
\mathrm{MC}^{\mathrm{b}} \\
\mathrm{MB}^{\mathrm{b}}\end{array}$ & $\begin{array}{l}-7.2 \\
\mathrm{MC}^{\mathrm{c}} \\
\mathrm{MB}^{\mathrm{c}}\end{array}$ & $\begin{array}{l}-4.1 \\
\mathrm{MC}^{\mathrm{c}} \\
\mathrm{MB}^{\mathrm{c}}\end{array}$ & $\begin{array}{l}-2.1 \\
\mathrm{MC}^{\mathrm{a}} \\
\mathrm{MB}^{\mathrm{a}}\end{array}$ & -2.5 & -0.1 & 2.6 & -2.3 \\
\hline 1993 & 2.0 & 2.2 & 0.4 & -0.8 & -2.1 & -3.6 & -2.8 & $\begin{array}{l}-3.2 \\
\mathrm{MC}^{\mathrm{a}}\end{array}$ & $\begin{array}{l}-3.0 \\
\mathrm{MC}^{\mathrm{a}}\end{array}$ & -1.4 & 0.2 & 0.8 & -0.9 \\
\hline 1994 & 2.2 & 1.6 & 1.1 & -1.0 & -3.6 & -3.4 & $\begin{array}{c}-10.3 \\
\mathrm{MC}^{\mathrm{a}}\end{array}$ & $\begin{array}{l}-3.3 \\
\mathrm{MC}^{\mathrm{a}} \\
\mathrm{MB}^{\mathrm{a}}\end{array}$ & $\begin{array}{l}-2.9 \\
\mathrm{MC}^{\mathrm{a}}\end{array}$ & -5.0 & 1.0 & 1.5 & -1.8 \\
\hline 1995 & 2.6 & 2.3 & 0.3 & -1.2 & -2.1 & $\begin{array}{l}-6.2 \\
\mathrm{MC}^{\mathrm{a}}\end{array}$ & $\begin{array}{c}-12.0 \\
\mathrm{MC}^{\mathrm{b}} \\
\mathrm{MB}^{\mathrm{b}}\end{array}$ & $\begin{array}{c}-10.3 \\
\mathrm{MC}^{\mathrm{c}} \\
\mathrm{MB}^{\mathrm{c}}\end{array}$ & $\begin{array}{l}-5.6 \\
\mathrm{MC}^{\mathrm{c}} \\
\mathrm{MB}^{\mathrm{c}}\end{array}$ & $\begin{array}{l}-0.8 \\
\mathrm{MC}^{\mathrm{a}} \\
\mathrm{MB}^{\mathrm{a}}\end{array}$ & -0.5 & 1.3 & -2.7 \\
\hline 1996 & 2.0 & 2.7 & 1.5 & 1.0 & -2.1 & -4.8 & -3.4 & -3.6 & -1.4 & -1.3 & -0.1 & 1.1 & -0.7 \\
\hline
\end{tabular}

MC, Marian Cove

station (Table 2). It seems that the sea is not frozen when the yearly mean air temperature is above $-2.0^{\circ} \mathrm{C}$.

We suggest that the retreat of ice tongues in these small Antarctic fjords may be related to the recent regional warming. Indeed, surface air temperatures measured on the west coast of the Antarctic Peninsula have shown long-term warming trends (King, 1994). One location on the Antarctic Peninsula has shown an increase of around $1.5^{\circ} \mathrm{C}$ over the past 30 years (Morrison, 1990). A mechanism that may explain this behaviour is that the fracture toughness of ice is reduced at higher temperatures and in the presence of meltwater (Sabol and Schulson, 1989). The meltwater percolates through the crevasses on the surface of the ice tongues down to the basal zone, opening them up (Doake and Vaughan, 1991).

\section{CONCLUSIONS}

This investigation shows that the ice cliffs are retreating possibly in response to the atmospheric warming in the area. The higher rate of retreat of ice cliffs in recent years may be the result of more rapid warming during this period.

The advance of the ice cliff observed in January 1989 suggests that the glaciers and ice flow around King George Island respond quickly to small temperature variations.

It is necessary to survey the ice cliffs around the fjords on King George Island periodically to confirm their temporal variations.

Further studies are necessary to confirm the hypothesis suggested for the disappearance of large areas of ice in Potter Cove in comparison to Marian Cove from December 1956 to January 1989.

\section{ACKNOWLEDGEMENTS}

Our sincere thanks are extended to anonymous referees for their constructive criticism. We also thank the Direccion
Meteorologica de Chile and the Instituto Antartico Chileno in Santiago for meteorological data from Presidente Eduardo Frei base on King George Island. This study was supported by the Polar Research Center, Korea Ocean Research and Development Institute, Seoul, Korea.

\section{REFERENGES}

Burgess, J. S., A. P. Spate and J. Shelvin. 1994. The onset of deglaciation in the Larsemann Hills, eastern Antarctica. Antarct. Sci., 6 4), 491-495.

Defense Mapping Agency Hydrographic/Topographic Center. 1980. Deception Island to King George Island. Washington, DC, Defense Mapping Agency Hydrographic/Topographic Center. (DMA 29AC029101, Scale $1: 200000$.

Doake, C. S. M. and D. G. Vaughan. 1991. Rapid disintegration of the Wordie Ice Shelf in response to atmospheric warming. Nature, 350 6316), 328-330.

Gordon, J. E. and R. J. Timmis. 1992. Glacier fluctuations on South Georgia during the 1970s and early 1980s. Antarct. Sci., 4(2), 215-226.

Instituto Hidrografico de la Armada de Chile (IHAC). 1980. Caleta Potter. Santiago, Instituto Hidrografico de la Armada de Chile. (Mapas 1410, Scale 1: 10000 .

Kim, Y. K. and W. D. Baek. 1995. [Bathymetric and topographic measurements around King Sejong Station, King George Island, Antarctica (II).] In Kim, D.Y., ed. [ The studies on natural environment and resources of Antartica.] Seoul, Korea Ocean Research and Development Institute (KORDI), 825-846. (BSP.N 00258-822-7.) [In Korean with English summary.]

King, J. C. 1994. Recent climate variability in the vicinity of the Antarctic Peninsula. Int. 7. Climatol., 14(4), 357-369.

Korea Ocean Research and Development Institute (KORDI). 1996. [ Topographic map of Barton Peninsula, King George Island (The King Sejong Station). Korea Ocean Research and Development Institute. (Scale 1:10000.) [In Korean with English summary.]

Morrison, S. J. 1990. Warmest year on record on the Antarctic Peninsula? Weather, 45(6), 231-232.

Sabol, S. A. and E. M. Schulson. 1989. The fracture toughness of ice in contact with salt water. F. Glaciol., 35(120), 191-192.

Skvarca, P. 1993. Fast recession of the northern Larsen Ice Shelf monitored by space images. Ann. Glaciol., 17, 317-321.

Vaughan, D. G. and C. S. M. Doake. 1996. Recent atmospheric warming and retreat of ice shelves on the Antarctic Peninsula. Nature, 379 (6563), 328-331.

Ward, C. G. 1995. Mapping ice front changes of Müller Ice Shelf, Antarctic Peninsula. Antarct. Sci., 7 (2), 197-198. 